\title{
Transduction of Myxococcus virescens by Coliphage P1CM: Generation of Plasmids Containing both Phage and Myxococcus Genes
}

\author{
By D. W. MORRIS, SUSAN R. OGDEN-SWIFT, \\ VIRPI VIRRANKOSKI-CASTRODEZA, K. AINLEY \\ AND J. H. PARISH \\ Department of Biochemistry, University of Leeds, 9 Hyde Terrace, Leeds LS2 9LS
}

(Received 9 January 1978)

Chloramphenicol-resistant Myxococcus virescens were obtained by infecting myxococci with Escherichia coli specialized transducing phage PICM. The drug-resistant myxococci were phenotypically unstable. They contained more than one type of plasmid; these plasmids were not found in the parent strain. Chloramphenicol-resistant $E$. coli were obtained by transformation with either a fraction of myxococcal DNA containing the plasmids or with P1CM prophage DNA. These transformants contained plasmids. Escherichia coli transformed by DNA from the myxococci contained both P1CM and myxococcal genes. Individual transformant clones differed in the genetic make-up of their plasmids. Among the myxococcal genes expressed in these plasmid-harbouring $E$. coli strains were a capacity for self-transmissibility and a pattern of phage sensitivity characteristic of $\mathbf{R}$ factor incompatibility group W. Escherichia coli transformed with P1CM prophage contained incomplete $\mathrm{P} 1 \mathrm{CM}$ genomes; none of the chloramphenicol-resistant transformants produced P1CM phage particles. The significance of these findings for an understanding of mechanisms for the generation of $\mathrm{R}$ factors is discussed.

\section{INTRODUCTION}

Members of the genus Myxococcus (Myxococcaceae, Myxobacterales) are Gram-negative rods which demonstrate gliding motility and aggregate to form simple fruiting bodies. Myxococci can acquire drug resistance by three different types of process. (i) Unstable resistance to chloramphenicol may be induced in $M$. xanthus by exposure of vegetative organisms to low concentrations of the drug (Burchard \& Parish, 1975). (ii) Unstable resistance to a variety of drugs (including chloramphenicol) may be acquired following incubation of mixtures of strains of either Escherichia coli or Pseudomonas fluorescens harbouring $\mathrm{R}$ factors with strains of either $M$. xanthus or $M$. fulvus (Parish, 1975). (iii) Chloramphenicol resistance may be acquired by $M$. xanthus following infection of vegetative cells with the specialized E. coli transducing phage P1CM (Kaiser \& Dworkin, 1975). P1 phage is not propagated by the myxococci and, as in (i) and (ii), the chloramphenicol-resistant myxococci are very unstable.

The last two types of procedure for the acquisition of drug resistance by myxococci imply that exogenous DNA (of plasmids or prophage) can survive in a myxobacterial host. In the present work we have examined the nature of the bacterial replicon which includes genes encoded in the exogenous DNA and present in the myxococcal host. We have chosen not to use the strains whose resistance is seemingly derived from $\mathrm{R}$ factors because of their extreme instability. Indeed, when such strains were examined after prolonged subculture in the 
presence of the drug, they appeared to have lost any R factor as udged by DNA:DNA hybridization (Morris, unpublished data). We conclude that this is because low intracellular levels of the drug eventually induce an endogenous resistance mechanism [process (i)] which results in loss of the selective advantage for retaining the $\mathrm{R}$ factor in the presence of the drug. Kaiser \& Dworkin (1975) did not characterize the DNA of their transductants and they were unable to obtain P1 phages from the chloramphenicol-resistant myxococci. It is therefore possible that their transductants were abortive and that the resistance was due to transient partial detoxication of the drug by P1CM and consequent induction of the system described by Burchard \& Parish (1975).

In this paper we describe work to characterize the nature of the replicon which includes the genes for chloramphenicol resistance in transductants of $M$. virescens by phage P1CM. Myxococcus virescens is closely related to $M$. xanthus but differs in details of its morphogenetic cycle (Parish, Wedgwood \& Herries, 1976). It was chosen for this work because there is no evidence of an inducible, endogenous chloramphenicol resistance system of the type found in $M$. xanthus.

\section{METHODS}

Organisms, phages and growth. Strains of bacteria and phages used in this work are listed in Table 1. Following an agreed international nomenclature for myxobacterial strains (Wireman \& Dworkin, 1977), the $M$. virescens parent strain has been designated HP300. This organism was previously referred to as strain $\mathrm{V} 2$ (Parish et al., 1976). New plasmids have been numbered from pBL1001 using the recommendations of Novick et al. (1976) for plasmid nomenclature. Plasmid Sa appears in the earlier literature as S-a. Bacteriophage $\mathrm{K} 7$ is a newly isolated double-stranded DNA phage with an icosahedral head and a long tail (Morris, Virrankoski-Castrodeza \& Parish, unpublished).

Bacteria were grown in shake culture at $30^{\circ} \mathrm{C}$. Medium for $M$. virescens was CTYE which contained $1 \%$ $(\mathrm{w} / \mathrm{v})$ Bactocasitone and $0.5 \%(\mathrm{w} / \mathrm{v})$ yeast extract; medium for $E$. coli was $\mathrm{L}$ broth which contained $1 \%(\mathrm{w} / \mathrm{v})$ tryptone, $0.8 \%(\mathrm{w} / \mathrm{v}) \mathrm{NaCl}$ and $0.8 \%(\mathrm{w} / \mathrm{v})$ yeast extract.

The P1CM strain used was the same as that employed by Kaiser \& Dworkin (1975); it carries a temperature-sensitive mutation in a gene required for the maintenance of lysogeny. Cultures of lysogens can therefore be grown at the permissive temperature $\left(30^{\circ} \mathrm{C}\right)$ and induced at the non-permissive temperature $\left(42{ }^{\circ} \mathrm{C}\right)$. Like all $\mathrm{P} 1$ phages, the prophage state is a stable plasmid which does not integrate into the $E$. coli chromosome (Ikeda \& Tomizawa, 1968).

Phages were assayed by standard procedures. Underlay contained $1.2 \%(\mathrm{w} / \mathrm{v})$ agar and overlay contained $0.8 \%(\mathrm{w} / \mathrm{v})$ agar. Overlay agar contained (in addition to the nutrients described for the growth media) $2.5 \mathrm{mM}-\mathrm{CaCl}_{2}, 1 \mathrm{mM}-\mathrm{MgSO}_{4}$ and (for P1 phages only) $0.1 \%(\mathrm{w} / \mathrm{v})$ glucose. Plates for phage assays were incubated at $37^{\circ} \mathrm{C}$. Chloramphenicol $\left(25 \mu \mathrm{g} \mathrm{ml}^{-1}\right)$ was included in media for selection and maintenance of chloramphenicol-resistant strains.

For conjugation of $E$. coli, mixtures of donor and recipient strains were incubated at $30^{\circ} \mathrm{C}$ in stationary culture prior to plating.

Escherichia coli strains were labelled with ${ }^{3} \mathrm{H}$ or ${ }^{14} \mathrm{C}$ by growth in minimal A medium (Miller, 1972) supplemented with appropriate amino acids (each $\left.4 \mu \mathrm{g} \mathrm{ml}^{-1}\right)$, deoxyadenosine $\left(25 \mu \mathrm{g} \mathrm{ml}^{-1}\right)$ and either [methyl $\left.{ }^{3} \mathrm{H}\right]$ thymidine $\left(47 \mathrm{Ci} \mathrm{mmol}^{-1}, 1.0 \mathrm{mCi} \mathrm{ml}^{-1}\right)$ or $\left[\right.$ methyl $\left.I^{14} \mathrm{C}\right]$ thymidine $\left(50 \mathrm{mCi} \mathrm{mmol}^{-1}, 50 \mu \mathrm{Ci} \mathrm{ml}^{-1}\right)$. Escherichia coli was labelled with ${ }^{32} \mathrm{P}$ by growth in the buffered salts of Garen \& Levinthal (1960), supplemented with glucose $(1 \%) \mathrm{w} / \mathrm{v})$, sodium $\beta$-glycerophosphate $(0 \cdot 14 \%, \mathrm{w} / \mathrm{v})$, appropriate amino acids (each $4 \mu \mathrm{g} \mathrm{ml}^{-1}$ ) and [ ${ }^{32} \mathrm{P}$ ]orthophosphate (carrier free, $1 \mathrm{mCi} \mathrm{ml}^{-1}$ ). Myxococcus virescens was labelled by growth in bovine serum albumin $(1 \%, \mathrm{w} / \mathrm{v}$; Fraction $\mathrm{V}$; Sigma) supplemented with the basal salts medium of Brockman (1973), sodium $\beta$-glycerophosphate $(0 \cdot 14 \%, \mathrm{w} / \mathrm{v})$, spermidine. $3 \mathrm{HCl}(0 \cdot 0024 \%, \mathrm{w} / \mathrm{v})$ and radiochemicals in the same amounts as were used for $E$. coli.

Indole production was detected by the method of Baker (1967).

* Abbreviations: $s t r, \mathrm{cml}, \mathrm{kan}$, amp, sul, tet, tmp and gen indicate resistances to streptomycin, chloramphenicol, kanamycin, ampicillin, sulphonamides, tetracycline, trimethoprim and gentamycin, respectively; $h s d R h s d M^{+}$, unrestrictive but modifying with respect to the $\mathrm{K} 12$ restriction-modification system; $d r d$, derepressed; Clr, clear plaque; $c l r 100$ is a temperature-sensitive mutation.

$\dagger$ In some strains of phages $\mathrm{Pl}$ and $\lambda$, the strain designation incorporates a partial definition of the genotype. In this paper, we have followed this practice in order to facilitate cross-reference to the rest of the literature and the phenotype ( $\mathrm{Clr}$ ) has been entered under genotype. Phages K7 and PR4 only plaque on E. coli strains harbouring $\mathrm{R}$ factors of certain incompatibility groups.

$\ddagger$ Letters in parentheses identify the incompatibility groups of the plasmids (Datta \& Hedges, 1972). 
Table 1. Bacterial strains, plasmids and phages

Relevant genotype*

Source

\section{Bacteria}

\begin{tabular}{ll}
\multicolumn{2}{l}{ Myxococcus virescens } \\
HP300 \\
HP312 cml \\
Escherichia coli $\mathrm{K} 12$ \\
802 & hsdR \\
W3 3110 & \\
TLA02 & trp lac arg $\mathrm{F}^{+}$ \\
J53 & \\
M508 \\
C600 & str pon \\
$\lambda^{-}$
\end{tabular}

Laboratory stock strain

This work

\section{Phages $\uparrow$}

P1CM

Plc4.32

$\mathrm{clr} 100 \mathrm{cml}$
$\mathrm{Clr}$
$\mathrm{Clr}$
$\mathrm{Clr}$
$\mathrm{Clr}$
$\mathrm{Clr}$
$\mathrm{Clr}$
$\mathrm{Clr}$
Host range
Host range

W. J. Brammar

Laboratory stock strain

S. Baumberg

Laboratory stock strain

S. Baumberg

Laboratory stock strain

P1 aml

P1 am4

P1 $\operatorname{am} 13$

P1 $\operatorname{am} 21$

P1 am31

$\lambda_{\text {vir }}$

K7

Host range
J. Rosner
J. Rothman Scott
J. Rothman Scott
J. Rothman Scott
J. Rothman Scott
J. Rothman Scott
J. Rothman Scott
Laboratory stock strain
See text
D. E. Bradley

Plasmids

\begin{tabular}{|c|c|}
\hline & \\
\hline R386 (FII) & amp str cml kan sul \\
\hline R1-19 (FII) & cml kan amp str sul drd \\
\hline R124 (FIV) & tet \\
\hline $\mathrm{R} 64(\mathrm{I} \alpha)$ & str tet \\
\hline R144-3 (I $\alpha)$ & kan drd \\
\hline $\mathrm{R} 483(\mathrm{I} \beta)$ & str tet \\
\hline $\operatorname{R621a}(\mathrm{I} \gamma)$ & tet \\
\hline $\mathrm{R} 721(\mathrm{I} \delta)$ & $t m p$ \\
\hline RA1 (A) & tet sul \\
\hline $\mathrm{R} 57 \mathrm{~b}(\mathrm{C})$ & cml amp kan sulgen \\
\hline $\mathrm{R} 27(\mathrm{H})$ & tet \\
\hline R371 (J) & kan \\
\hline R387 (K) & str $\mathrm{cml}$ \\
\hline R471a (L) & $a m p$ \\
\hline R446b (M) & str tet \\
\hline $\mathrm{R} 46(\mathrm{~N})$ & amp str tet sul \\
\hline R390 (N) & cml amp str sul tet \\
\hline $\mathrm{R} 16(\mathrm{O})$ & amp str tet sul \\
\hline RP4 (P) & amp tet kan \\
\hline $\mathrm{R} 478(\mathrm{~S})$ & tet $\mathrm{cml} \mathrm{kan}$ \\
\hline Rts-1 (T) & kan \\
\hline $\mathrm{Sa}(\mathrm{W})$ & $\mathrm{cml} \mathrm{kan} \mathrm{str} \mathrm{sul}$ \\
\hline R7K (W) & $a m p$ \\
\hline R6K (X) & $a m p$ str \\
\hline $\operatorname{SSu}(-)$ & str sul \\
\hline pBL1003 & $\mathrm{cml}$ \\
\hline pBL1005 & $\mathrm{cml}$ \\
\hline pBL.1009 & $\mathrm{cml}$ \\
\hline pBL1010 & $\mathrm{cml}$ \\
\hline pBL1011 & $\mathrm{cml}$ \\
\hline pBL1013 & $\mathrm{cml}$ \\
\hline pBL1014 & $\mathrm{cml}$ \\
\hline pBL 1016 & $\mathrm{cml}$ \\
\hline pBL1017 & $\mathrm{cml}$ \\
\hline pBL1021 & $\mathrm{cml}$ \\
\hline pBL1024 & $\mathrm{cml}$ \\
\hline
\end{tabular}

S. Baumberg

S. Baumberg

S. Baumberg

S. Baumberg

S. Baumberg

S. Baumberg

S. Baumberg

S. Baumberg

S. Baumberg

S. Baumberg

S. Baumberg

S. Baumberg

S. Baumberg

S. Baumberg

S. Baumberg

S. Baumberg

S. Baumberg

S. Baumberg

S. Baumberg

S. Baumberg

S. Baumberg

S. Baumberg

R. W. Hedges

S. Baumberg

S. Baumberg

This work

This work

This work

This work

This work

This work

This work

This work

This work

This work

This work

For footnotes to table see opposite page 
Transduction with bacteriophage $\mathrm{P} 1 \mathrm{CM}$. Escherichia coli $\mathrm{W} 3110(\mathrm{P} 1 \mathrm{CM})$ was grown to exponential phase at $30{ }^{\circ} \mathrm{C}$ in $\mathrm{L}$ broth and lysed by incubation for $90 \mathrm{~min}$ at $42^{\circ} \mathrm{C}$ in the presence of $1 \mathrm{mM}-\mathrm{Mg}^{2+}$. Chloroform ( 1 to $2 \mathrm{ml}$ ) was then added, and the lysate was clarified by centrifugation and assayed using E. coli c600 as indicator.

Transduction of $M$. virescens $\mathrm{HP} 300$ with bacteriophage $\mathrm{P} 1 \mathrm{CM}$ was performed as described for $M$. xanthus by Kaiser \& Dworkin (1975).

Preparation of plasmid DNA. P1CM prophage DNA was isolated from E. coli $3110(\mathrm{P} 1 \mathrm{CM})$ by the method of Clewell \& Helinski (1969). Otherwise, plasmid DNA was isolated from 'cleared lysates' of plasmidcarrying strains of $M$. virescens and $E$. coli by a modification of the method of Currier \& Nester (1976). A culture in exponential phase $(500 \mathrm{ml})$ was harvested by centrifugation, washed twice in TES buffer ( $0.05 \mathrm{M}$-Tris/HCl, $0.5 \mathrm{M}-\mathrm{NaCl}, 0.005 \mathrm{M}-\mathrm{EDTA}, \mathrm{pH} 8.5)$ and lysed by incubating for $30 \mathrm{~min}$ at $37^{\circ} \mathrm{C}$ in the presence of $0.5 \mathrm{mg}$ pronase $\mathrm{ml}^{-1}$ (Sigma, predigested by incubation at $37^{\circ} \mathrm{C}$ for $90 \mathrm{~min}$ ) and $1 \%(\mathrm{w} / \mathrm{v})$ sodium lauryl sulphate. Chromosomal DNA was sheared by forcing the lysate through a syringe and needle (18 gauge) six times, denatured by raising the $\mathrm{pH}$ to 12.0 to $12 \cdot 3$ for $10 \mathrm{~min}$ and neutralized. Denatured DNA was removed by extraction with redistilled, water-saturated phenol, and the phenol was removed by extraction with chloroform/isoamyl alcohol $(24: 1, \mathrm{v} / \mathrm{v})$. Plasmid DNA was precipitated by treatment with ethanol and magnesium phosphate at $-20^{\circ} \mathrm{C}$ (Dessev \& Grancharov, 1973). The precipitate was redissolved in a minimum volume of $0.1 \mathrm{M}$-EDTA, pH 8.0 , and dialysed against TES buffer. For density-gradient centrifugation, $5 \mathrm{ml}$ portions were taken; $\mathrm{CsCl}$ and ethidium bromide $(3.75 \mathrm{mg})$ were dissolved to achieve a density of $1.57 \mathrm{~g} \mathrm{ml}^{-1}$ (Flamm, Birnstiel \& Walker, 1972). The samples were centrifuged for $60 \mathrm{~h}$ at $40000 \mathrm{rev} . \mathrm{min}^{-1}$ and $16{ }^{\circ} \mathrm{C}$ in a Beckman type SW50.1 rotor. Plasmid DNA was removed by fractionation from the bottom of the tube or by withdrawal of visibly stained zones with a syringe needle. Ethidium bromide was removed from DNA by extraction with isoamyl alcohol and $\mathrm{CsCl}$ was removed by dialysis.

For fractionation of DNA from cleared lysates by column chromatography, the solution (in $0.1 \mathrm{M}$-EDTA, pH 8.0) was first passed through a column of Sepharose 4B to remove protein and RNA (Šatava, Zadraižil \& Šormová, 1973). The fractions containing DNA were pooled and fractionated by chromatography on hydroxyapatite in the presence of ethidium bromide (Pakroppa, Goebel \& Müller, 1975).

Electron microscopy of plasmid DNA. DNA samples were prepared by the aqueous technique of Davis, Simon \& Davison (1971). Grids were stained in uranyl acetate and then rotary shadowed with platinum and examined with a Philips EM200 microscope at an operating voltage of $60 \mathrm{kV}$. The original magnifications were between $\times 5000$ and $\times 9200$ and pictures were recorded on $35 \mathrm{~mm}$ film. Certain negatives were printed. Otherwise they were projected, traced and contour lengths were measured with a map measurer.

DNA:DNA hybridization. For hybridization experiments, sheared unfractionated bacterial DNA was prepared by the method of Berns \& Thomas (1965). Approximately $0 \cdot 01 \mu \mathrm{g}{ }^{3} \mathrm{H}$-labelled sheared denatured plasmid P1CM DNA (1000 to 3000 c.p.m.) was incubated with $200 \mu \mathrm{g}$ non-radioactive denatured sheared bacterial DNA, annealed in $0.42 \mathrm{M}-\mathrm{NaCl}$ at $60^{\circ} \mathrm{C}$ for $16 \mathrm{~h}$ and digested with S1-nuclease to remove singlestranded DNA. Radioactivity was assayed in the remaining double-stranded DNA. Preparation of S1nuclease and methods of sample preparation and assay of radioactivity were according to Crosa, Brenner \& Falkow (1976).

Transformation. Escherichia coli was transformed with P1CM prophage plasmid DNA and preparations of plasmids from M. virescens HP312 by the method of Mandel \& Higa (1970) with the following modifications. The $\mathrm{CaCl}_{2}$ concentration was $0.1 \mathrm{M}$. The 'heat shock' consisted of incubating organisms at $42{ }^{\circ} \mathrm{C}$ for $2 \mathrm{~min}$; then the bacteria were chilled for $90 \mathrm{~min}\left(0^{\circ} \mathrm{C}\right)$. Deoxyribonuclease was not added to the mixture. The transformation mixture was diluted $1: 10$ in $\mathrm{L}$ broth and incubated for 4 to $6 \mathrm{~h}$ at $30^{\circ} \mathrm{C}$ to permit phenotypic expression of chloramphenicol resistance prior to plating on selective medium.

\section{RESULTS}

\section{Properties of transduced Myxococcus virescens}

By transducing $M$. virescens HP300 with bacteriophage P1CM with a multiplicity of infection of 5, chloramphenicol-resistant organisms were produced at a frequency of approximately $5 \times 10^{-6}$ per cell. This is comparable with the frequency obtained when M. xanthus was transduced in the same way (Kaiser \& Dworkin, 1975). One such chloramphenicol-resistant transductant, $M$. virescens HP312, was used for further analysis.

The chloramphenicol resistance in $M$. virescens HP312 is extremely unstable. After transfer to unselective medium, chloramphenicol-sensitive segregants appeared after $5 \mathrm{~h}$ (Fig. 1). The erratic growth curve for the organism is due to the fact that $M$. virescens HP300 and its 


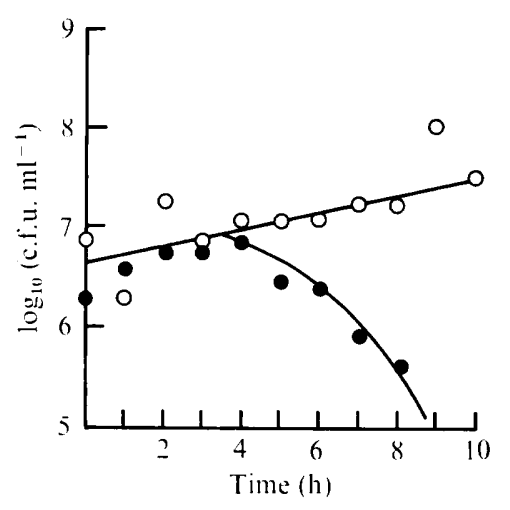

Fig. 1

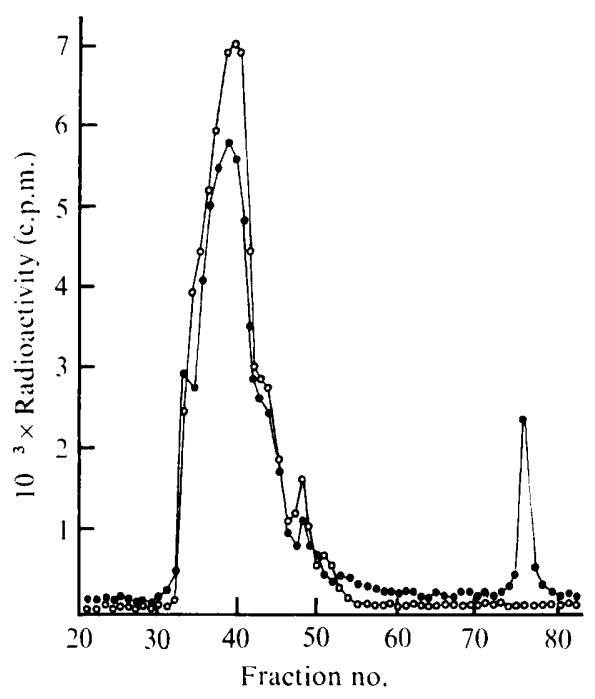

Fig. 2

Fig. 1. Instability of $M$. virescens HP312 in unselective medium. Organisms were grown in CTYE medium supplemented with chloramphenicol $\left(25 \mu \mathrm{g} \mathrm{ml}^{-1}\right)$ and diluted into CTYE at time 0 . At intervals, portions were removed, diluted and the numbers of colony forming units (c.f.u.) were measured by plating on CTYE agar containing chloramphenicol (O) and CTYE agar without chloramphenicol $(\bigcirc)$.

Fig. 2. Fractionation of DNA from 'cleared lysates' by hydroxyapatite-ethidium bromide chromatography (see Methods). DNA of cultures of $M$. virescens strains HP300 and HP312 was labelled with ${ }^{14} \mathrm{C}$ and ${ }^{3} \mathrm{H}$, respectively. Cleared lysates were prepared and mixed so that equal amounts of ${ }^{14} \mathrm{C}$ and ${ }^{3} \mathrm{H}$ radioactivity were present, and the solution was then fractionated. Radioactivity $\left({ }^{14} \mathrm{C}, \mathrm{O} ;{ }^{3} \mathrm{H}, \mathrm{O}\right)$ was determined in each sample by liquid scintillation counting; quenching and overlap corrections were made. Plasmids were present in fraction 77.

derivatives grow in a semi-disperse form in liquid media and, as with certain other myxococci, small clumps accumulate and disperse during growth (Parish, 1975).

Analysis of DNA from a 'cleared lysate' of $M$. virescens HP312 revealed the presence of a DNA fraction which adsorbed strongly to hydroxyapatite in the presence of ethidium bromide. This is evidence for the presence of covalently closed DNA (Pakroppa et al., 1975). Such material was not found in cleared lysates from strain HP300 (Fig. 2).

Electron microscopic examination of the fraction of HP312 DNA which adsorbed to the hydroxyapatite column revealed three types of molecule. Small plasmids (Fig. 3) were found; these had an apparent molecular weight (determined from contour length measurements) of $1.9 \times 10^{6}$. Larger molecules were also found; these had an apparent molecular weight of $8.7 \times 10^{6}$. Every molecule of this type was associated with a 'blob' of darkly staining material (Fig. 4). Careful examination of the photographic negatives suggested that the DNA molecule is probably covalently continuous, and the blobs are likely to be fragments of plasma membrane. This is supported by the constancy of the molecular weight of these molecules. However we have not rigorously ruled out the possibility that the molecules could be fragments from larger plasmids present in the eluate from the hydroxyapatite column and, indeed, there is evidence that much larger plasmids must be present in these preparations (next section). The electron microscope grids also contained DNA of an extremely tangled appearance with no visible ends. These structures were not apparently supercoiled and it has not been possible to measure their contour lengths nor to establish whether or not they are covalently closed. 


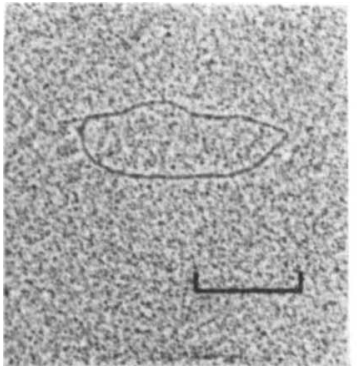

Fig. 3

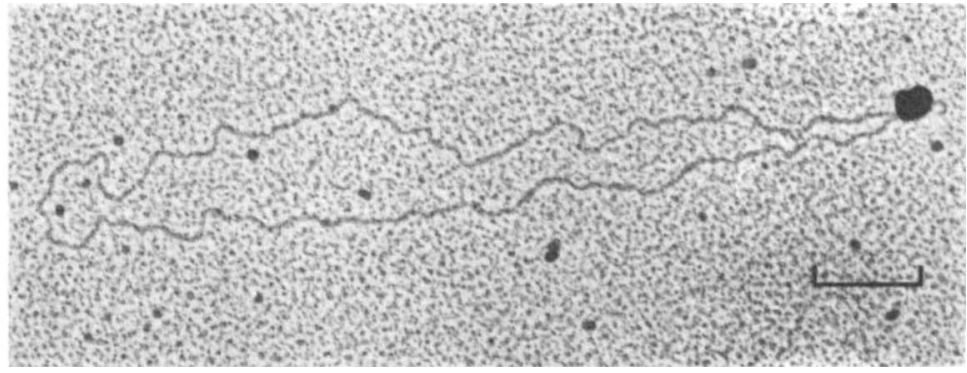

Fig. 4

Figs 3 and 4. Electron micrographs of plasmids from 'cleared lysates' of $M$. virescens HP312. Bar markers represent $0 \cdot 2 \mu \mathrm{m}$.

\section{Properties of E. coli strains transformed with DNA from M. virescens $\mathrm{HP} 312$ and $\mathrm{P} 1 \mathrm{CM}$ prophage}

A fraction of $M$. virescens HP312 cleared lysate DNA was enriched for covalently closed DNA by CsCl-ethidium bromide buoyant-density centrifugation. Escherichia coli 802 (an unrestrictive but modifying strain) was transformed with this DNA. By using $3 \mu \mathrm{g}$ DNA $\mathrm{ml}^{-1}$ and $3 \times 10^{9}$ bacteria $\mathrm{ml}^{-1}$ in the transformation mixture, chloramphenicol-resistant $E$. coli transformants were obtained at a frequency of approximately $10^{-7}$ per cell. In a separate experiment using P1CM prophage plasmid DNA and the same conditions, chloramphenicol-resistant transformants were obtained at a frequency of approximately $10^{-6}$ per cell. In the description of plasmid-harbouring $E$. coli strains obtained in this way, we refer to those in which the transforming DNA was obtained from HP312 as $\mathrm{cm} / 312$ and to those in which the transforming DNA was obtained from P1CM prophage as $\mathrm{cm} / \mathrm{P} 1 \mathrm{CM}$. All the chloramphenicol-resistant transformants were stable and chloramphenicol-sensitive organisms have not segregated in unselective liquid medium at any measureable frequency.

None of the strains tested (four of the type $\mathrm{cmlP} 1 \mathrm{CM}$ and nine of the type $\mathrm{cm} / 312$ ) produced P1CM phage following growth at the non-permissive temperature for maintenance of P1CMclr 100 lysogens. From this we conclude that none of these organisms contained a complete P1 genome. We believe that the failure to obtain intact P1CM genomes by transformation with $\mathrm{P} 1 \mathrm{CM}$ prophage is due to the transformation event selecting for that proportion (approximately $20 \%$ ) of $\mathrm{P} 1$ prophage plasmids which naturally delete extensive parts of their genome (Yun \& Vapnek, 1977). We have independently confirmed that a proportion of the prophage plasmids obtained from our strain of $E$. coli w3110 (P1CM) are shorter by amounts comparable with the data of Yun \& Vapnek (1977).

We have characterized the DNA from one transformant, E. coli 802 (pBL1005) $\mathrm{cm} / 312$. Analysis by ethidium bromide- $\mathrm{CsCl}$ buoyant-density centrifugation confirmed the presence of the plasmid pBL1005 in this organism (Fig. 5). Electron microscopic examination of DNA from the plasmid peak of gradients such as that illustrated in Fig. 5 showed two types of molecule which are the relaxed and supercoiled conformations of the plasmid (Figs 6 and 7). From contour length measurements of relaxed forms (such as Fig. 6), the apparent molecular weight of pBL1005 is $68.8( \pm 0.45) \times 10^{6}$. This is significantly larger than any plasmid found in $M$. virescens HP312 (previous section). We therefore conclude that we have so far failed to observe in the electron microscope plasmids such as pBL1005 in the myxococci from which they were derived.

Plasmid pBL1005 was transferred from E. coli 802 to $E$. coli TLA02 by conjugation. Transconjugants appeared after $1 \mathrm{~h}$ (Fig. 8). This type of transfer was not demonstrated by E. coli $802(\mathrm{pBL1003}) \mathrm{cm} / \mathrm{P} 1 \mathrm{CM}$. The genetic exchange of chloramphenicol resistance demonstrated in Fig. 8 did not occur with culture supernatants from E. coli 802(pBL1005) $\mathrm{cml} 312$ and was therefore not due to transduction. This conclusion was confirmed by show- 


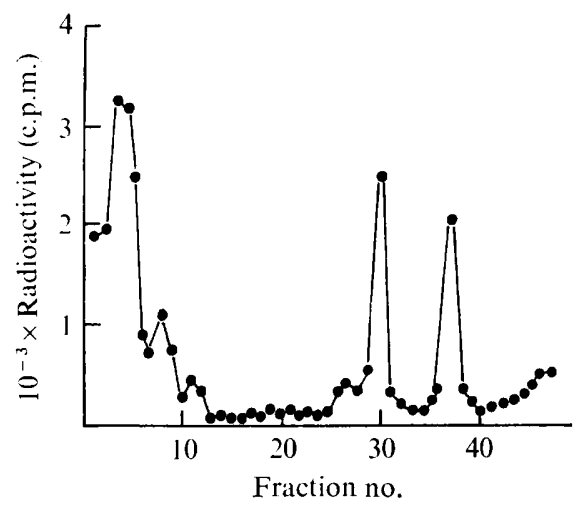

Fig. 5. Fractionation of DNA from a 'cleared lysate' of E. coli 802 (pBL1005) $\mathrm{cm} / 312$ by ethidium bromide- $\mathrm{CsCl}$ buoyant-density centrifugation. Organisms were labelled with $\left[{ }^{3} \mathrm{H}\right]$ thymidine (see Methods); after centrifugation, fractions were assayed for radioactivity by liquid scintillation counting. Fraction 1 is the bottom of the gradient. Plasmid DNA was present in the peak in fraction 30; the peak in fraction 37 was $E$. coli chromosomal DNA. The peak at the bottom of the gradient was presumed to contain RNA-DNA-protein aggregates.

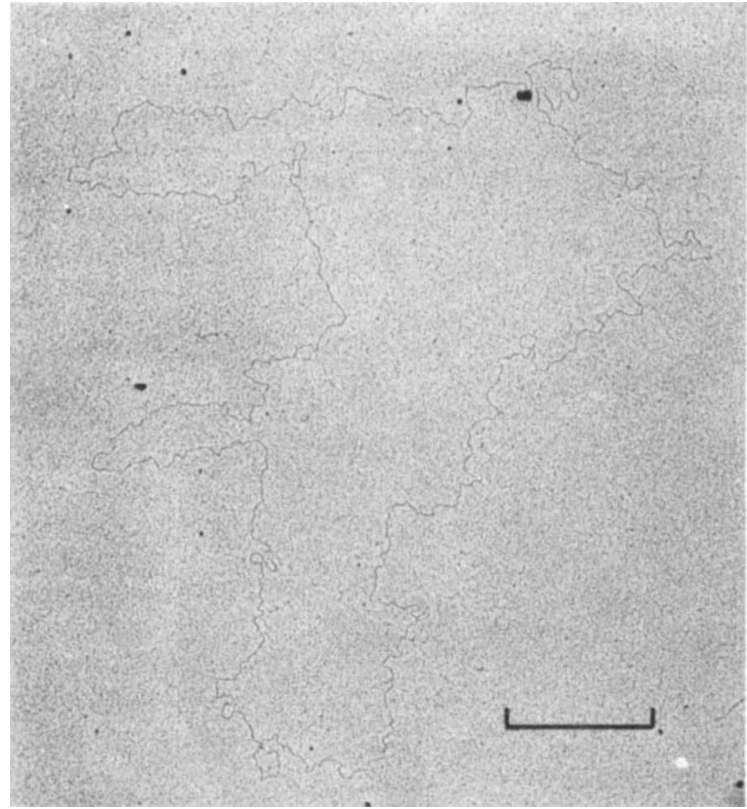

Fig. 6

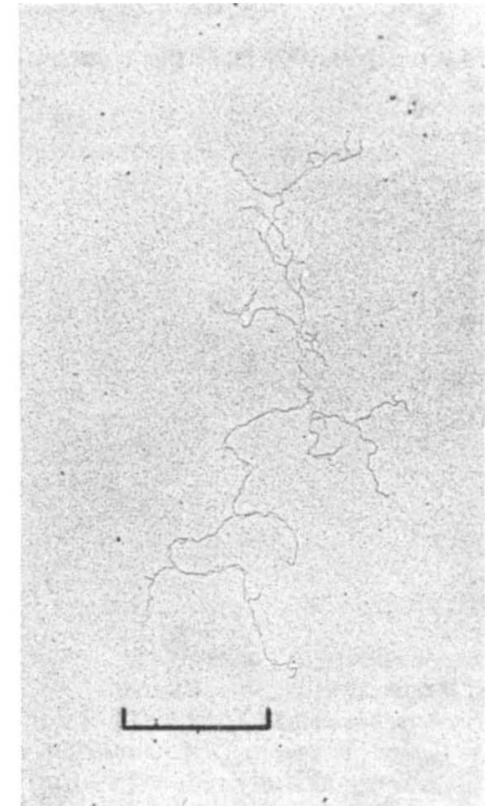

Fig. 7

Figs 6 and 7. Electron micrographs of plasmids from 'cleared lysates' of E. coli 802(pBL1005) cml312. Bar markers represent $1.0 \mu \mathrm{m}$. See text for discussion.

ing that a mutant of $E$. coli which lacks a P1 receptor (strain M5086) is a successful recipient in such a transfer. As P1CM prophage is not a self-transmissible plasmid, the transfer function in pBL1005 must be of myxococcal origin. A second phenotypic change in $E$. coli 802 following acquisition of pBL1005 is that the cells become hosts for a newly isolated double-stranded DNA phage K7. (Details of the properties of this phage will be published elsewhere.) Escherichia coli 802 and $802(\mathrm{P} 1 \mathrm{CM})$ are not hosts for the phage and therefore K7-sensitivity must rely upon expression of myxococcal genes in pBL1005. Twenty-five E. coli strains harbouring R factors (Table 1) of different incompatibility groups were tested 


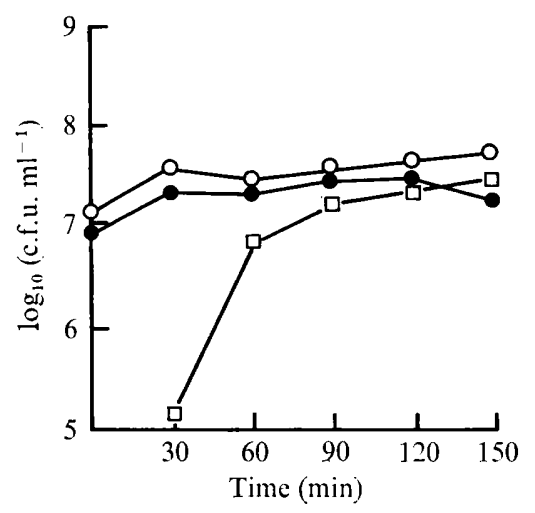

Fig. 8. Conjugal transfer of chloramphenicol resistance from E. coli 802(pBL1005) to E. coli TLA02. At intervals, portions of culture were removed, diluted and plated, and numbers of colony forming units (c.f.u.) of strains 802(pBL1005) (O), TLA02 (๑) and TLA02(pBL1005) ( $\square$ ) were determined using suitable selective media. The chloramphenicol-resistant transconjugant colonies were tested on lactose indicator medium and were found to be lac. This constituted a test for an unselected marker in the transconjugants because strain 802 is $\mathrm{lac}^{+}$and TLA02 is lac.

\section{Table 2. Comparison of the phenotypes of E. coli 802 strains harbouring plasmids}

Plasmid pBL1003 is of the type $\mathrm{cm} / \mathrm{P} 1 \mathrm{CM}$; all other pBL plasmids in this table are of the type

P1CM hsp

Plasmid

Sensitivity to phage $\mathbf{~}^{*}$

$$
\mathrm{cm} / 312 \text { (see text). }
$$

$$
\quad \text { Rescue of P1 markers\| }
$$

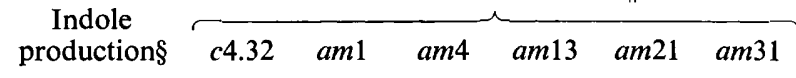
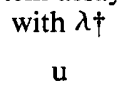

$u$
$r$
$u$
$\ddagger$
$u$
$u$
$u$
$u$
$u$
$u$
$u$
$u$
$u$

\begin{tabular}{|c|c|c|c|c|c|}
\hline- & - & - & - & - & - \\
\hline$i$ & $i$ & $i$ & $i$ & $i$ & 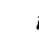 \\
\hline- & - & + & - & + & - \\
\hline+ & + & + & + & + & - \\
\hline- & - & + & + & - & - \\
\hline NT & $\mathrm{NT}$ & NT & NT & NT & $\mathrm{N}$ \\
\hline+ & - & - & - & - & - \\
\hline- & + & + & + & + & - \\
\hline- & - & - & - & - & - \\
\hline+ & + & + & + & + & - \\
\hline - & - & - & - & - & \\
\hline$\ldots$ & - & - & - & - & \\
\hline & + & - & - & - & \\
\hline
\end{tabular}

$$
\begin{gathered}
++ \\
++ \\
++ \\
- \\
++ \\
+ \\
++ \\
++ \\
++ \\
- \\
++ \\
++ \\
++
\end{gathered}
$$

$*+$, Sensitive; - , insensitive.

$\dagger \mathrm{r}$, Restrictive; u, unrestrictive.

$\ddagger$ Escherichia coli 802 (pBL1005) is not a host for phage $\lambda$.

$\S++$, Indole production in nutrient qualitatively similar to wild type; + , indole production just detectable but significantly reduced; - , no indole detectable.

$\|+$, Marker rescued (i.e. plaques turbid); - , marker not rescued (plaques clear); $i$, immune; NT, not tested.

as possible hosts for phage K7. The only hosts [apart from E. coli (pBL1005) and strains harbouring other $\mathrm{cml} 312$ plasmids] were $E$. coli $(\mathrm{Sa})$ and $E$. coli $(\mathrm{R} 7 \mathrm{~K})$. Both of these last two plasmids belong to incompatibility group W (Watanabe, Furuse \& Sakaizumi, 1968; R. W. Hedges, personal communication). Genes for this or a related incompatibility group are therefore present in $M$. virescens HP300 and are presumptively associated with the transfer function. The presence of the determinants of such an incompatibility group was independently confirmed by testing with phage PR4. This phage is specific for $E$. coli strains with either W or P group pili (Bradley, 1976; Bradley \& Cohen, 1977). Of four $\mathrm{cml} 312$ plasmids tested (pBL1009, pBL1010, pBL1013 and pBL1016), all were hosts for phage PR4.

Escherichia coli $802(\mathrm{pBL} 1005)$ does not produce indole when grown on a catabolite-free 
nutrient medium. The reason for this is unknown but we believe that it may be due to an inhibition of the activity of the catabolite repressible protein (CRP) because indole production in $E$. coli is due to the expression of the tna operon and expression of this operon shows a strong catabolite effect (Khairul Bashar, Parish \& Brown, 1971). Strain TLA02(pBL1005) does produce indole. The difference may reflect a dependence upon the genetic background of the E. coli strain or may be due to segregation of pBL1005 following conjugative transfer.

Several independently isolated strains of $E$. coli containing $\mathrm{cml} / 312$ plasmids were compared to establish whether they were identical and to estimate the part of the P1CM genome present in these plasmids. For this latter purpose, we attempted to rescue defined Pl genes by superinfecting the strains with $\mathrm{P} 1$ phages carrying conditional mutations in $c$ genes. These mutations define genes required for products needed for the maintenance of lysogeny. The phages carry amber mutations and were passaged through $E$. coli 802 . The phages selected for the study all form clear plaques on E. coli 802 as indicator and the mutations in $c$ genes in these phages are therefore not suppressed by the suppressor mutation ( $u p E$ ) present in this strain. When strains harbouring plasmids were used as indicators, certain phages produced turbid plaques. The phages in these plaques were not further characterized and we cannot say whether the maintenance genes were rescued by recombination or complementation. Many of the plaques were extremely small and 'turbidity' was recognized as the presence of lysogenic colonies seen in the plaques when these were examined under a microscope (35× magnification). The pattern of rescue of maintenance genes differed markedly between different strains of $E$. coli harbouring different plasmids. These data are summarized in Table 2 together with other phenotypic properties of the strains.

The data show that all the new $\mathrm{cm} / 312$ plasmids confer K 7-sensitivity and none of them confers the P1 restriction-modification system. The other phenotypes vary. The effect on indole production is only manifest in three plasmids of those tested (pBL1005, pBL1010 and pBL1016). The greatest variation in the plasmids occurs in the region which contains P1 genes. These results show that a culture of $M$. virescens HP312 must be heterogeneous with respect to its plasmid complement and that the myxococcal-P1CM hybrid plasmids in these organisms form a mixture undergoing genetic recombination.

The data of Table 2 imply that extensive parts of the P1CM genome are present in pBL1005 and other $\mathrm{cm} / 312$ plasmids and hence, by implication, in $M$. virescens HP312. This was independently confirmed by DNA:DNA hybridization using radioactive P1CM phage DNA as a probe. Of the order of $70 \%$ of the P1CM sequences are present in the plasmids tested (pBL1005 and pBL1010) and of the same order of magnitude in $M$. virescens HP312 and also $M$. virescens $\mathrm{HP} 315 \mathrm{cml}$. This latter organism is an independently isolated P1CM transductant of $M$. virescens $\mathrm{HP} 300$.

\section{DISCUSSION}

Our data show that recombinational events between phage P1CM DNA and an endogenous myxococcal replicon occurs within $M$. virescens HP312. Analysis of $E$. coli transformants with HP312 plasmid-enriched DNA generates a diverse set of plasmids as evidenced by the different properties of, for example, pBL1005, pBL1010 and pBL1024. This implies that strain HP312 contains an unstable population of plasmids. The transformation experiment effectively uses $E$. coli 802 to clone specific recombinants. Analysis of the P1CM markers present in the $\mathrm{cm} / 312$ plasmids shows that several recombinational events have occurred because there are gaps between P1 markers that can be rescued (Fig. 9).

In order to account for our findings we propose the following unified hypothesis for the fate of P1CM DNA in $M$. virescens. Strain HP300 is presumed to contain a replicon which can exist as a plasmid (possibly the plasmid is always present in HP300 cells; so far we have no experimental evidence on this point as no endogenous plasmid has been found). The replicon includes genes for incompatibility group W. Upon infection, P1CM recombines 


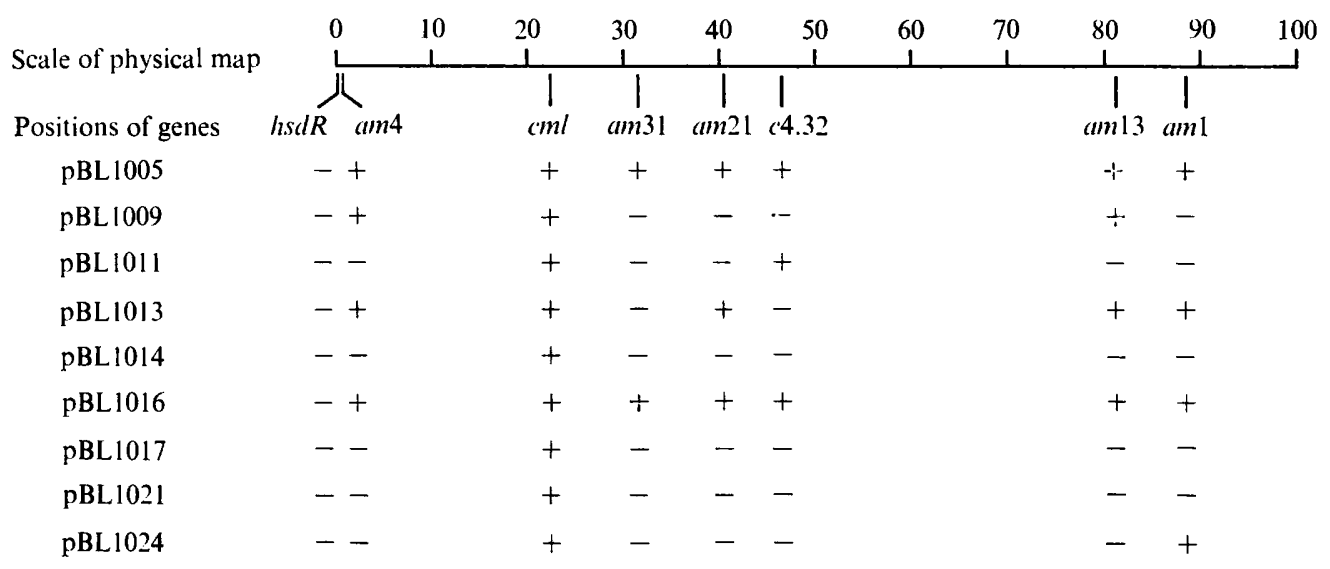

Fig. 9. Summary of the presence or absence of certain P1CM genes in pBL cml312 plasmids. $h s d R$ denotes restriction; other markers are defined by clear plaque mutations or chloramphenicol resistance. The order of the mutations is from Scott \& Kropf (1977) and the positions on the physical map from Yarmolinsky (personal communication). A + indicates the presence and expression of a gene in a plasmid. A - indicates lack of expression. If it is assumed that this implies absence of the gene, there must be at least one region deleted between any + which are interspersed by one or more - in a horizontal line.

with the replicon by an unknown mechanism. If P1CM is unable to circularize in the unnatural host (which seems reasonable), then at least two recombinational events are required to generate a plasmid. This accounts in part for the fragmentation of the P1CM genome in the $\mathrm{cm} / 312$ plasmids. Subsequent growth of HP312 and further site-specific recombination generates a mixture of segregants. There is direct evidence for this in the mixture of plasmid types in HP312 and the heterogeneity of the $\mathrm{cml} 312$ plasmids. We believe it is likely that the only plasmids which survive in $M$. virescens $\mathrm{HP} 312$ are those which use the myxococcal (as opposed to the P1) origin of replication. The instability of strain HP312 in the absence of chloramphenicol reflects the fact that chloramphenicol is selecting for those organisms in which there is association of the origin of the replicon in HP300 with the chloramphenicol gene of P1CM.

We have designed a method for cloning certain myxococcal plasmid genes in $E$. coli. The technique should prove of value in genetic studies on members of the genus Myxococcus. Of greater ecological importance is the process whereby previously independent incompatibility and resistance genes are brought together. Myxococci are widely distributed in surface soil, rotting vegetation and animal droppings. Plasmid pBL1005 cm/312 and its relatives are new $\mathrm{R}$ factors constructed by association of a drug resistance element and certain linked genes (in this case P1 genetic markers) with a new incompatibility group, following genetic exchange (probably involving site-specific recombination) in such an organism. Bearing in mind the prevalence of myxococci in pasture land and the widespread use of antibiotic drugs in veterinary medicine, the mechanism is a clear indication of a likely process for the reassortment of drug resistance genes in the environment.

We are grateful to Drs S. Baumberg and R. W. Hedges and Professors J. Rothman Scott, W. J. Brammar, D. E. Bradley and J. Rosner for generous gifts of phages and bacterial strains and to Mr A. Mountain for suggesting technical details of the transformation method. This work was supported by grants (to J.H.P.) from the Medical Research Council. 


\section{REFERENCES}

BAKER, F. J. (1967). Handbook of Bacteriological Technique, p. 259. London: Butterworths.

Berns, K. 1. \& Thomas, C. A., Jr (1965). Isolation of high molecular weight DNA from Hemophilus influenzae. Journal of Molecular Biology 11, 476-490.

Bradley, D. E. (1976). Adsorption of the R-specific bacteriophage PR4 to pili determined by a drug resistance plasmid of the $\mathrm{W}$ compatibility group. Journal of General Microbiology 95, 181-185.

Bradley, D. E. \& Cohen, D. R. (1977). Adsorption of lipid-containing bacteriophages PR4 and PRD1 to pili determined by a P-1 incompatibility group plasmid. Journal of General Microbiology 98, 619-623.

Brockman, E. R. (1973). Isolation of myxobacteria from marine habitats in the U.S. Virgin Islands. In Estuarine Microbial Ecology, pp. 45-51. Edited by L. H. Stevenson \& R. R. Colwell. Columbia, South Carolina: University of South Carolina Press.

Burchard, R. P. \& Parish, J. H. (1975). Chloramphenicol resistance in Myxococcus xanthus. Antimicrobial Agents and Chemotherapy 7, 233-238.

Clewell, D. B. \& Helinski, D. R. (1969). Supercoiled circular DNA-protein complex in Escherichia coli: purification and induced conversion to an open circular DNA form. Proceedings of the National Academy of Sciences of the United States of America 62, 1159-1166.

Crosa, J. H., Brenner, J. \& Falkow, S. (1976). Use of a single-strand specific nuclease for analysis of bacterial and plasmid deoxyribonucleic acid homo- and heteroduplexes. Journal of Bacteriology 115, 904-911.

Currier, T. C. \& Nester, E. W. (1976). Isolation of covalently closed circular DNA of high molecular weight from bacteria. Analytical Biochemistry 76, 431-441.

DatTA, N. \& Hedges, R. W. (1972). Host ranges of $\mathrm{R}$ factors. Journal of General Microbiology $\mathbf{7 0}$, $453-460$.

Davis, R. W., Simon, M. \& Davison, N. (1971). Electron microscope heteroduplex methods for mapping regions of base sequence homology in nucleic acids. In Methods of Enzymology XXI, 413-428.

Dessev, G. N. \& Grancharov, K. (1973). Precipitation of RNA, DNA and nucleoprotein particles from very dilute solutions. Analytical Biochemistry 53, 269-271.

Flamm, W. G., Birnstiel, M. L. \& Walker, P. M. B. (1972). Isopycnic centrifugation of DNA: methods and applications. In Subcellular Components: Preparation and Fractionation, pp. 279 310. Edited by G. D. Birnie. London and Baltimore: Butterworths and University Park Press.

Garen, A. \& Levinthal, C. (1960). A fine structure genetic and chemical study of the enzyme alkaline phosphatase of E. coli. I. Purification and characterization of alkaline phosphatase. Biochimica et biophysica acta 38, 470-483.

IKeDA, H. \& Tomizawa, J. (1968). Prophage P1, an extrachromosomal replication unit. Cold Spring Harbor Symposia on Quantitative Biology 33, 791-798.

KAISER, D. \& Dworkin, M. (1975). Gene transfer to a myxobacterium by Escherichia coli phage P1. Science 187, 653-655.

Khairul Bashar, S. A. M., Parish, J. H. \& Brown, M. (1971). Biosynthesis in vitro of tryptophanase by polyribosomes from induced cultures of Escherichia coli. Biochemical Journal 123, 355-365.

Mandel, M. \& Higa, A. (1970). Calcium-dependent bacteriophage DNA infection. Journal of Molecular Biology 53, 159-162.

Miller, J. H. (1972). Experiments in Molecular Genetics. Cold Spring Harbor, New York: Cold Spring Harbor Laboratory Press.

Novick, R. P., Clowes, R. C., Cohen, S. N., Curtiss, R., III, DatTa, N. \& Falkow, S. (1976). Uniform nomenclature for bacterial plasmids: a proposal. Bacteriological Reviews 40, 168-189.

PAKroppa, W., Goebel, W. \& Müller, W. (1975). Isolation of closed circular duplex DNA by chromatography on hydroxyapatite in the presence of ethidium bromide. Analytical Biochemistry 67, 372-383.

Parish, J. H. (1975). Transfer of drug resistance to Myxococcus from bacteria carrying drug-resistance factors. Journal of General Microbiology 87, 198-210.

Parish, J. H., Wedgwood, K. R. \& Herries, D. G. (1976). Morphogenesis in Myxococcus xanthus and Myxococcus virescens (Myxobacterales). Archives of Microbiology 107, 343-351.

ŠATAVA, J., ZADRAižIL, S. \& Šormová, Z. (1973). Isolation of transforming DNA from Bacillus subtilis by gel filtration on Sepharose 4B. Collection of Czech Chemical Communications 38, 2167-2173.

ScOTT, J. R. \& KROPF, M. M. (1977). Location of new clear plaque genes on the P1 map. Virology 82, 362-368.

Watanabe, T., Furuse, C. \& Sakaizumi, S. (1968). Transduction of various $R$ factors by phage $P 1$ in Escherichia coli and by phage P22 in Salmonella typhimurium. Journal of Bacteriology 96, 17911795.

Wireman, J. W. \& Dworkin, M. (1977). Developmentally induced autolysis during fruiting body formation by Myxococcus xanthus. Journal of Bacteriology 129, 796-802.

YUN, T. \& VAPNEK, D. (1977). Electron microscopic analysis of bacteriophages P1, P1CM and P7: determination of genome sizes, sequence homology and location of antibiotic resistance determinants. Virology 77, 376-385. 